\title{
Meira Paibis Movement Roles in Creating Peace at Northeastern India
}

\author{
Derina Faslig Silitonga \\ Universitas Muhammadiyah Yogyakarta
}

\begin{abstract}
Starting from the aim of stopping the rebel movement, the enactment of the Armed Forces Special Powers Act (AFSPA) of 1958 in practice became a boomerang for security stability in Northeastern India. The privileges granted by the government to soldiers are used as a pretext for discrimination and violations of human rights. The patriarchal tradition, which then considers women as property and weak creatures, causes women and children to suffer the most. Reports of sexual harassment cases, rape, and even murder unilaterally encouraged Meira Paibis as a grassroots women's movement to develop a strategy of resistance. Meira Paibis uses a non-violent approach through symbolic methods that are viewed as extreme and controversial in its mission. This research will describe the significant role of the Meira Paibis women's movement in organizing resistance to AFSPA policies and their efforts to achieve positive peace in Northeastern India. This paper will elaborate on the non-violence approach to see the strategies played by Meira Paibis and the obstacles faced in the process of achieving her goals.
\end{abstract}

Keywords: Women's Movement; Non-Violence; Meira Paibis; Human Rights Violations; Peace

Berawal dari tujuan untuk menumpas pemberontakan, penegakkan kebijakan Armed Forces Special Powers Act atau AFSPA tahun 1958 dalam praktiknya menjadi bumerang bagi stabilitas keamanan di kawasan Timur Laut India. Hak istimewa yang diberi oleh pemerintah kepada tentara justru menjadi bentuk justifikasi untuk tindakan diskriminatif dan pelanggaran hak asasi manusia. Dengan tradisi patriarkis yang memandang wanita sebagai objek properti dan makhluk yang lemah, mengakibatkan wanita dan anak-anak menjadi korban yang paling menderita. Laporan akan kasus kejahatan seksual, pemerkosaan, hingga pembunuhan secara sepihak mendorong Meira Paibis sebagai pergerakan wanita untuk mengembangkan strategi resistansi. Meira Paibis menggunakan pola pendekatan tanpa kekerasan melalui metode-metode simbolik yang dipandang sebagai hal yang ekstrem dan kontroversial dalam misinya. Melalui penelitian ini, penulis akan mendeskripsikan peran signifikan yang dilakukan oleh pergerakan wanita Meira Paibis dalam mengorganisir tindakan resistensi terhadap kebijakan AFSPA dan usaha mereka dalam mewujudkan bentuk perdamaian positif di kawasan Timur Laut India. Tulisan ini akan menjelaskan lebih lanjut mengenai pendekatan tanpa kekerasan untuk melihat bentuk strategi yang digunakan oleh Meira Paibis dan tantangan yang dihadapi dalam prosesnya untuk mencapai tujuannya.

Kata kunci: Gerakan Wanita; Tanpa Kekerasan; Meira Paibis; Kejahatan Kemanusiaan; Perdamaian 


\section{Introduction}

Manipur is an Indian state located in the Northeast, directly bordering Myanmar. The conflict and violence in Manipur were rooted from the government's failure to integrate the sentiments of the minority people in policymaking. In 1947, with the end of British rule, Manipur had become an independent country. However, this condition did not last long because, in practice, the Maharaja of Manipur at that time had signed a document as an instrument of accession to join India. Manipur was declared officially as a state in India in 1949. From the Manipur people's perspective, the accession agreement to join the Manipur region to India was a form of unilateral coercion. The emergence of economic and social problems then prompted the emergence of rebel groups to separate themselves from India. Large demonstrations took place that included women's groups to go down the road to demand state status (Sharma 2014, 19-20).

In response to the rebellion, the Indian government imposed the Armed Forces Special Powers Act on 11 September 1958, known as AFSPA. In short, AFSPA gives the armed forces the power to maintain public order at "disturbed areas". The area is to be defined when the government is satisfied that there is, or was, an area within the state which saw an extensive disturbance of public peace and considered disturbed due to differences or disagreements between members of the religion, race, language or regional groups and different castes (Singh 2019, 55-56; The Disturbed Areas (Special Courts) Act 1976, 1). The Manipur state was first given a 'disturbed area' stature in 1980 to fight the four rebel groups active. AFSPA grants the armed forces the authority to prohibit the gathering of five or more people in an area. The armed forces are also allowed to use power or even open fire at someone who is considered breaking the law. The soldier is also given special authority to arrest parties without a warrant, enter or search the premises without a warrant and prohibit the possession of firearms (Ngaihte 2015).

Even though it had a good initial aim, namely to maintain regional order from the ideology and rebel groups, on the other hand this policy has caused controversy. Reports of acts of sexual violence, forced killings and other human rights violations committed by the armed forces surface. it is suspected that more than 1,528 people were killed in extrajudicial killings by soldiers in Manipur (BBC 2017). In response, a group of women in 1980 came to express the problems experienced by the community in Manipur either before or after the AFSPA policy was implemented. The women's movement became known as Meira Paibis or the Woman's Torch Bearer. Meira Paibi is a women's social movement that has become known as the guardian of society. This movement exists to speak about state cruelty and 
human rights violations in Manipur (Chakravarti 2010, 52).

The movement, which has been massively active since 1980, has not received a good response from the Indian government. Reports of sexual harassment by soldiers against women and children are increasing. Every day, there are civil society groups that are declared victims of deliberate murder while the AFSPA policy is still being implemented. The peak of the movement then occurred in 2004 when twelve elderly women positioned themselves in front of the Kangla Fort gates to voice their acts of disillusionment and protest against the AFSPA soldiers and the government. The protest was followed by a demonstration, raising banners with various vulgar remarks related towards the soldier's sexually-natured atrocities that they committed. The Meira Paibis movement used their own bodies as a means to oppose the ongoing discrimination in the Manipur region (Ray 2018, 5-6).

This movement was successfully heard by the Chief Minister of Manipur, who subsequently issued a commitment to fight for peace and follow up on problems in Manipur. However, the government still has no desire to repeal the AFSPA policy. This caused the Meira Paibis movement to continue and evolved into the largest grassroots movement in Manipur and even India. The Meira Paibi has been active in demonstrations for weeks against the AFSPA policy and other human rights violations. This movement continues to fight in peaceful and symbolic ways as a form of resistance. In 2011, this movement received international attention where the UN directly requested the withdrawal of the AFSPA in the Northeastern region of India (Meitei 2016).

Until now, Meira Paibi movement is still active in advocating for human rights justice, protecting women and children, and demanding the revocation of AFSPA. The existence of Meira Paibi is increasingly visible at the forefront of political mobilization and public space. This women's group continues to prepare new strategies to meet all the goals they want to achieve (Ray 2018, 10). Therefore, through the following research, the author will analyze how significant the Meira Paibis women's movement role in creating peace, mainly positive peace, in India's Northeastern region.

\section{Literature Review and Theoretical Framework}

Many articles and studies have already discussed Northeastern India's conflicts and the resistance movement carried out, especially by women. 
The following articles will then provide an overview of the conflict and the presence of the Meira Paibis women's movement in India. Research on Understanding Women's Activism of Manipur: The Meira Paibis Movement (Singh 2019) by Laishram J. Singh explains that women activists are generally registered in the history of the struggle for independence in India. Women have played an important role in socio-economic life as well as in cultural and religious practices. The author then explains the history of the development of the women's movement that can be traced since the British rule. Starting in the 1980s, the Meira Paibis movement evolved by becoming increasingly visible at the forefront of political mobilization and the public sphere. This movement is then present as a movement for improvement purposes. The author then explained that this movement succeeded in creating a space for women to appear in public and fight for demands to be heard. Meira Paibis managed to break the old historical dichotomy against the political realm dominated by male groups. The author also touched on the controversy of Meira Paibis in 2004 in opposing ongoing discrimination, human rights violations, and sexual violence by AFSPA members. At the end of his writing, the author also describes the government's response to Meira Paibi's actions. PM Manmohan Singh said that violence must be shunned, and peace must be immediately created for sustainable development.

Next, Reading Women's Protest in Manipur: A Different Voice? by Paromita Chakravarti. This research discusses the importance of women's protests in Manipur concerning the history of the colonial territory's exploitation and the Indian state and women's involvement in social, economic, and peace-building activities. The author then explains the Manipur region's background and the history of its merger with India in 1949. Although India known to be a patriarchal country, women have remained at the forefront of the political movement throughout history. The initial rebellion was even able to overthrow the British regime and local monarchy. The author also reviewed the Manipur women's protests against the AFSPA killings and rapes in 2004. The stripping demonstrations carried out by Meira Paibis in front of the Indian Army headquarters urged soldiers to come to rape as a form of resistance (Chakravarti 2010).

The study is entitled Political motherhood and spectacular resistance: (Re) examining the Kangla Fort Protest, Manipur (Ray 2018) by Panchali Ray. This research was initiated by describing the movement to reexamine the Kangla protest at Manipur in 2004, where 12 mothers held protests by exposing themselves as a form of protest. This research analyzes the articulation of naked demonstrations by the group of mothers 
by looking at how they should rise, save the Manipur people from the authorities cruelty. The author examines the narrative of 'political motherhood' in which this group operates in their war paradigm as peacemakers. However, on the other hand, the demonstration is contrary to social, historical, and cultural norms. At the end of his article, the writer said that this movement was at least able to give new meaning to resistance politics in India.

The last research entitled Voyages of Women in Manipur towards a peaceful society (Meitei 2016) by Leitanthem Umakanta Meitei. This paper focuses on the analysis of how women in Manipur participate in peacebuilding. The author divides the Meira Paibis group into two classifications. First, Meira Paibis acts as a pressure group to prevent and protect local people from acts of violence by state and non-state armed groups. Second, Meira Paibi's role as an NGO working for peace campaigns. The author then presents his views on peacebuilding, which requires the identification of the root causes of conflict. In the context of Manipur, most of the problems were caused by the failure to integrate popular sentiment into policymaking. Although Meira Paibi's participation is only seen in a traditional role and has not touched the decision-making realm, the authors agree that the Women's Network has a crucial role in maintaining peace in Manipur and even India.

From some of the authors findings above regarding conflict-related research in Northeastern India and the resistance movement by women, no one has specifically discussed the role of the Meira Paibis women's movement in creating peace in Northeastern India. Some of the writings above have not analyzed the Northeastern state's current conditions. Aside from that, the existence of resistance carried out by Meira Paibis also have not properly analyzed. Therefore, the following research will specifically explain the role of the Meira Paibis women's movement in creating peace in Northeastern India from a non-violence movement perspective.

Johan Galtung classified the notion of peace into two conditions. First, negative peace is defined as a condition where there is no war and violence at the macro level. However, violence is still found at the policy level, or that causes inequality. Second, Galtung explained about positive peace. Where the conditions created were no violence at either the micro or macro level. This peace is enduring, optimistic, and preventive. In peace policy, this can be found in arbitration, conflict management, or international cooperation (Grewal 2003). The positive peace condition described by Johan Galtung above is a condition currently being fought for by the people of Northeastern India. Human rights violations have become a persistent problem in Manipur. 
Jørgen Johansen's non-violence approach is fundamental to explain the significant role of Meira Paibi movement. Non-violence is defined as a condition when there is no violence either directly, structurally, or culturally. In conflict situations, non-violence is not always the first choice in resolving or dealing with conflicts. The need for non-violence in a war is that there is no further damage. This is done because when using violence to face a problem, the result is counter-violence and becomes a spiral of violence that can escalate out of control (Johansen 2007, 143-145). Technically, the Non-Violence movement is interpreted as a term for various resistance methods that do not use violence against other parties. This method is considered useful for opposing and combating violence without using non-violence, creatively resolving conflicts, and developing just and peaceful alternatives (Nicholasen 2019).

In his writing, Johansen classifies the non-violence tradition into two parts: the pacifist tradition and the pragmatic tradition. The pacifist view does not accept any justification for the use of violence, be it direct or psychological. The idea that can be found in this religious teaching states that violence is a violation of the norm of non-violence. Mahatma Gandhi is a pacifist figure who uses the non-violence movement in the Ahimsa concept. Ahimsa prioritizes human values by not attacking, hurting, and even hurting other parties. Although in practice, this concept is considered too passive towards life. Next, the pragmatist view has a spectrum but is mostly closer to simply 'not killing' or avoiding the violence that causes only severe harm. On certain occasions, pragmatists consider violence that is not so detrimental to occur still. According to groups that adhere to pragmatics, it is not enough to avoid violence, but there must be actions to stop the violence (Johansen 2007, 145-148).

Then, Johansen explained that there are three categories in the pragmatic non-violence movement. First, a non-violence protest is a peaceful opposition where the perpetrator expresses support or disapproval of a particular thing by communicating a message to the public. These messages are usually conveyed through symbols or slogans, marches, and protest meetings. Second, a non-cooperation practice where actors express resistance to something and withdraw their participation from practices that are not approved. The form of this category can be seen from the existence of embargoes, strikes, and boycotts. In non-cooperation practices, parties use influence to change the level of cooperation that may exist because of benefit or fear of the consequences. Third, a non-violence intervention when the actors withdraw from participation and actively try to stop the practice they are opposed to. The level of intervention can be done by presenting a third party on a small to large scale (Johansen 2007, 
149-150). The non-violence movement can be found in the act of achieving democratic conditions in a region, struggling for human rights, opposing racism and sexism, demanding economic and political justice, and the environmental protection movement. In this research, the framework of non-violence will be used as an analytical tool to see the role of the Meira Paibis women's movement in creating peace in Northeastern India.

\section{Meira Paibis as Non-Violence Movement}

Johansen technically explained that the non-violence movement is defined as a term of various kinds of resistance that do not use violence against other parties. Although not always the first choice in resolving conflicts or reaching demands, non-violence methods are considered useful in fighting creatively, not to cause further damage. One form of non-violent resistance can be seen from the Meira Paibis women's movement in Northeastern India. The women's movement has a long tradition of socio-economic life, such as in agricultural production and distribution of crops. On the other hand, the women's movement has a much more significant role in the socio-political order, especially in achieving stability, security, and peace.

In the case of resistance by women's movement groups in Northeastern India, Meira Paibi's non-violent resistance can be categorized into pragmatic traditions, specifically in non-violence protest. This is because the Meira Paibis attitude thinks it is not enough to avoid it responding to violent or injustice behavior. Still, there must be actions to stop the violence. The acts of resistance by Meira Paibis were categorized into formal and informal conventional strategies. Meira Paibis used to reach demands using a communication approach such as dialogue or negotiation to convey the legal form's needs. Meanwhile, the informal conventional strategy is carried out through street campaigns.

Meira Paibi's conventional strategy began to appear in 1970, which also marked the women's movement in Manipur. During this period, the movement was carried out due to public unrest about the effects of using and selling liquor at Northeastern India (Potsangbam 2016, 65-66). However, this movement is still limited and has not received widespread attention. The Meira Paibis women's movement's turning point came in 1980 when security forces under the Armed Forces Act 1958 (AFSPA) were deployed to parts of Northeastern India to control insurgent forces. The existence of privileges and legitimacy of superiority before the law has led to the security forces abuse of power. One of them concerns the point "Every assigned official, non-commissioned officer or other equal as possible, in the disturbed area, if he thinks that it is necessary for the maintenance of public order, after giving a proper warning such as he may 
consider it necessary, shoot or using force even to the point of death, against anyone who acts contrary to law and order temporarily in force in the disturbed area" (Ranjan 2015, 245-256).

The above points and other regulations have led to mistreatment by the security members towards civil society, mostly women and children. Treatment of violence, discrimination, sexual harassment, and other gross human rights violations are carried out by security personnel under the pretext of maintaining order. During this period, several cases came to the public's attention from killing innocent children to the point of torturing them to death without warning, to 10 civilians considered part of a rebel conspiracy. In response to this action, the Manipur women's group defended peaceful protest to free other detained civilians. Meira Paibis also held parades while lighting torches throughout the night as a form of action to maintain regional security (Ranjan 2015, 259-261).

After incidents of oppression, discrimination, and unilateral killing by soldiers in the Manipur area, the Meira Paibis women's movement has increasingly aggressively declared its opposition to the AFSPA law's implementation. Massive resistance was carried out through general meetings, negotiations, road blockages, and hunger strikes (Chakravarti 2010). However, in the following periods, Meira Paibis made more significant and specific resistance for women and children. This is because often in conflict or war, women and children suffer the most. Bullying, sexual harassment, and rape are carried out based on the construction that women are property and are considered a winning way to show who controls the property. Structurally, women are considered the weak party to legitimize to denigrate women both symbolically and physically as rape (Kaplan 1994, 5-7).

One of the cases committed by AFSPA soldiers towards women and children, which later received public attention, was the Thangjam Manorama case in July 2004. Manorama was kidnapped by three Assam Rifles personnel who was a unit of the Indian Army, and several hours later, her body was found not far from his house was in a state of gunshot marks on his body. It is indicated that Manorama was tortured and raped by the soldiers (Basnet 2019). As a women's group that was active in guarding the AFSPA soldiers actions, Meira Paibis spontaneously devised a strategy to counter the incident. Meira Paibi's resistance strategy was carried out more aggressively. The group of middle-aged women, who were Meira Paibis, did not only carry out parades carrying torches and blocking the Assam Riffles battalion. When they arrived in front of the battalion gate, the 12 Meira Paibis member took turns stripping themselves. With loud voices, they shouted the banner's contents that had been brought 
The Meira Paibis used their bodies as a medium to convey demands and resistance in a totality, material, communicative, and contextual. The naked bodies that they show are symbolic of the unrest they have felt since enacting the special privilege policy on AFSPA soldiers (Ranjan 2015, 254256). Every day women in Northeastern India feel threatened and unsafe under the AFSPA policy and its privileges for the soldiers. Army groups monitor women almost every day and assume that women are private property that they can treat sexually every day. Using their bodies, Meira Paibis opposed the AFSPA soldiers to come out and gave them the option to rape them in public or protect the people of Manipur (VeneracionRallonza 2014).

Meira Paibi's grassroots resistance continues as, in practice, the government still maintains the AFSPA army's privileges. Hence, there are still reports of arbitrary actions by AFSPA soldiers in the Manipur region. Privileges cause perpetrators of sexual abuse never to get sanctioned. April 2015, reports of rape incidents occurred again. During this period, reports came about the rape by soldiers of a 13-year-old girl. The soldiers also persecuted his mother and grandmother, who tried to save the teenager. Anger returned to the surface. Meira Paibis returned with their strategy to prosecute the soldiers heinous actions and again appealed to the government to amend or even revoke privileges to the army immediately (Ranjan 2015).

Although not by exposing himself to the public, the strategy used by Meira Paibis was still considered quite aggressive. The Meira Paibis are actively conducting parades with torches as a form of security guarding in Manipur. Collectively, they take a peaceful communication approach to negotiate policy amendments. Sometimes they moved to block several soldiers battalions and the streets carrying banners bearing their demands. The grassroots women's movement is also active in fasting or on hunger strikes as a form of solidarity for the victims of oppression and discrimination who have died (Singh 2020). Until the end of January 2019, Meira Paibis was still seen actively holding torchlight parades for weeks on the streets as part of their demands for the Indian government to revoke its privileges through AFSPA immediately (Nepram 2019).

The explanation above reflects that the actions taken by Meira Paibis are a form of the non-violence practical approach to the category of non-violence protest. In responding to acts of discrimination, sexual harassment, and other gross human rights violations, Meira Paibi is not only silent but moves to formulate a strategy to end the violence. Meira Paibi's strategy of non-violence shows a spectrum of merely 'not killing' or avoiding the violence that causes serious consequences. Meira Paibis, with 
the explanation of non-violence protest, expressed their disapproval of the government by using symbols and slogans. Such symbolic actions can be seen from stripping oneself, banner slogans, fasting marathons, to torch parades. The torch, which became the hallmark of the women's movement, was even articulated as a weapon of just war and a sacred symbol of the resistance movement (Veneracion-Rallonza 2014).

\section{Meira Paibis Challenges and Achievements in Promoting Peace at Northeastern India}

The non-violence method is considered creatively useful in developing just and peaceful alternatives in resolving conflicts or claims based on discrimination. Proponents of this approach assume that at least nonviolence does not make the conflict more widespread or does not lead to further violence (Johansen 2007). However, there is a possibility that emerging challenges may hinder the non-violence movement's success in its implementation. Such possibility is not excluded in the case of Meira Paibis women's movement in fighting against the Indian government.

The Meira Paibis movement's main challenge stems from a patriarchal tradition that is deeply rooted in Northeastern India's government and security apparatus. Women are labeled as property or symbols of territory. Acts of sexual harassment and rape were carried out as a form of victory for the security forces against rebel groups who wanted to separate from Indian territory (Ranjan 2015). The security apparatus that carried out these heinous acts rarely received the government's spotlight and rarely received sanctions before the law. On the other hand, the patriarchal tradition can be seen from the government structure in response to Meira Paibis demands. In the deliberation process on policies or those that take place between the government and the female security apparatus, it is rarely included as a resource (Nepram 2019). Women in cases of oppression under AFSPA are the most disadvantaged. This then led to the deliberations again, not in favor of women and children. Thus, the Meira Paibis movement continued even with the same patterns and methods.

Another challenge comes from the absolute superiority given by the Indian government to the AFSPA security apparatus. The privileges granted by the government allowed soldiers to take any action, including removing evidence and manipulating evidence of persecution. This has happened in the case of rape committed by the Assam Rifles Army unit. The perpetrator manipulated evidence to the victim, such as grenades and other sharp objects, to prove that the victim was part of the rebels. The evidence is used to legalize the acts of rape and murder committed by the Assam Rifles so that the government cannot impose sanctions above the law on these 
soldiers (Potsangbam 2016).

Several challenges have hindered Meira Paibi's non-violence movement and made it challenging to achieve several goals. However, the struggle carried out from the 1980 os does not mean that it has not brought significant changes to Northeastern India's socio-political conditions. In the non-violence movement carried out by Meira Paibis against cases of oppression or rape, such as those in 1980 and 2004, the women's group succeeded in encouraging the government to form a human rights group, Jeevan Reddy Justice Committee, to investigate AFSPA's actions (Goswami 2010). The aggressive act of stripping oneself successfully pushed the Assam Rifles troops to evacuate the Kangla battalion base. Meira Paibis also succeeded in confronting the army, rescuing and liberating the youth group, unilaterally labeled as a rebel group. In 2014, Meira succeeded in encouraging the Indian government to provide compensation in funding to families of victims of bullying and abuse (Arora 2020).

Meira Paibi's grassroots movement has grown to become a yardstick for protests against AFSPA and other social discrimination in Manipur. Through its adopted non-violence strategies, Meira Paibis has succeeded in gaining public attention for the prolonged suffering that has been felt by the Manipur people since the implementation of the AFSPA "black law" The loud voice of Manipur women has also been heard by the international community and the United Nations. Meira Paibis has successfully discussed their concerns before the UN in Geneva and New York. Meira Paibis has also succeeded in forging alliances with several global organizations such as the Nobel Women Initiative, the International Women's League for Peace and Freedom, and the International Peace Bureau (Nepram 2019).

On another social level, Meira Paibis formed a patrol group to guard and supervise women and children from military threats. This group massively parades each night with torches. Meira Paibis also plays a role in maintaining family security and resilience. Women's groups are present as mediators in violence cases that occur in the family and actively provide education. The Meira Paibis also managed to oversee the spread of narcotics and alcohol, one of the causes of social crimes (Gaikwad 2009). 


\section{Conclusion}

Since the enactment of the Armed Forces Special Powers Act on 11 September 1958, Northeastern India's people have lived under prolonged pressure. The policy that gave privileges to the army gave legitimacy to the military to act arbitrarily under protecting the territory from rebel groups. The patriarchal tradition, labelling women as property, and the structural assumption that women are weak creatures cause women and children to suffer the most from this Law's enactment. Starting in 1980, cases of oppression, sexual harassment, rape, to murder unilaterally continue to pressure the civil society at Manipur. To achieve peace, especially in form of positive peace in the Manipur area, the Meira Paibis women's movement came to provide resistance. This movement significantly applies the non-violence approach to carrying out its guidance.

The submission of demands is carried out symbolically through parades carrying torches, expressing slogans, fasting, leaving hair loose, barefoot to extreme actions such as being naked in public. This pragmatic nonviolence approach is carried out so that the impact of violence and conflict does not spread and has such a worrying effect. The inherent patriarchal tradition and the superiority of soldiers who were able to manipulate evidence of a crime were factors hindering the Meira Paibis movement's success. However, this does not state that this movement did not significantly impact the social, political conditions, and even peace in Manipur. Meira Paibis has succeeded in becoming a model for India's grassroots movement. The loud voices of Manipur women have succeeded in reaching the international arena because they have successfully negotiated with the United Nations and forged alliances with global organizations. Until now, Meira Paibi's struggle continues as torch parades as a sacred symbol of the peace movement are still often carried out to achieve positive peace in all layers of the Manipur region. 


\section{Bibliography}

\section{Book}

Johansen , J., 2007. "Nonviolence: More than the Absence of Violence", in Webel, Charles and Johan Galtung, 2007. Handbook of Peace and Conflict Studies. London: Routledge.

\section{Journal Articles}

Arora, V., 2020. "Citizens, the Smoking Guns of AFSPA and Bare Life in Northeast India”, Sociological Bulletin, 69 (3):351-67.

Basnet, M., 2019. "Disrobed and Dissenting Bodies of the Meira Paibi: Postcolonial Counterpublic Activism", Communication and the Public, 4 (3):239-52.

Chakravarti, P., 2010. "Reading Women's Protest in Manipur: A Different Voice?”, Journal of Peacebuilding \& Development, 5 (3):47-60.

Gaikwad, N., 2009. "Revolting Bodies, Hysterical State: Women Protesting the Armed Forces Special Powers Act (1958)", Contemporary South Asia, 17 (3):299-311.

Goswami, U., 2010. "Armed in Northeast India: Special Powers, Act or No Act", Peace and Conflict Review, 4 (2):1-14.

Kaplan, L. D., 1994. "Woman as Caretaker: An Archetype That Supports Patriarchal Militarism ", Hypatia: A Journal of Feminist Philosophy, 9 (2):123-33.

Ngaihte, T., 2015. "Armed Forces in India's Northeast: A Necessity Review”, South Asia Research, 35 (3):368-85.

Ranjan, A., 2015. "A Gender Critique of AFSPA: Security for Whom?", Social Change, 45 (3):440-57.

Ray, P., 2018. "Political Motherhood and a Spectacular Resistance: (Re) Examining the Kangla Fort Protest, Manipur", South Asian History and Culture, 9 (4):435-48.

Sharma, Aparajita, 2014. "Irom Chanu Sharmila and the Movement against Armed Forces Special Powers Act (AFSPA)", Space and Culture, India, 1 (3):18-26.

Singh, L. J, 2020. “Reconstructing Women's Nude Protest in Manipur 
Manipur through Oral History: Public Memory, Women's Identity", International Journal of Creative Research Thoughts, 8 (9):28942900.

Veneracion-Rallonza, M. L., 2014. "Women's Naked Body Protests and the Performance of Resistance: Femen and Meira Paibi Protests against Rape”, Philippine Political Science Journal, 35 (2):251-68.

\section{Working Paper}

Meitei, L. U., 2016. "Voyages of Women in Manipur Towards a Peaceful Society”, Peace Research Institute Oslo Paper.

\section{Conference Paper}

Singh, L. J., 2019. "Understanding Women's Activism of Manipur: The Meira Paibis Movement”, in International Conference on Women's Empowerment, Laws, Feminism, Gender Discrimination, Gender Space and Women's Leadership: Issues and Challenges in 21st Century. 9 November.

\section{Thesis and Dissertation}

Potsangbam, K., 2016. A Study on the Social Movements by the Women Civil Society Organizations (Meira Paibis) in Manipur State. Doctoral Thesis. Pune: Department of Social Work at Faculty of Arts, Social Sciences \& Commerce at University of Bharati Vidyapeeth Deemed.

\section{Acts of Parliaments}

The Disturbed Areas (Special Courts) Act, 1976. New Delhi: Ministry of Law and Justice.

\section{Online Articles}

BBC, 2017. "Counting the Dead in Manipur's Shoot-to-Kill War" [online]. In [https://www.bbc.com/news/world-asia-india-40271353] (accessed [23 January 2021]).

Grewal, B. S., 2003. "Johan Galtung: Positive and Negative Peace" [online]. In [http://www.activeforpeace.org/no/fred/Positive Negative Peace.pdf] (accessed [23 January 2021]). 
Nepram, B., 2019. "The Meira Paibis: The Brave Mothers of Manipur at the Forefront of a Strong Nonviolent Resistance Movement” [online]. In [https://www.nonviolent-conflict.org/blog post/the-meira-paibis-the-brave-mothers-of-manipur-at-the-forefront-of-a-strong-nonviolent-resistance-movement/] (accessed [23 January 2021]).

Nicholasen, M., 2019. "Nonviolent Resistance Proves Potent Weapon" [online]. In [https://news.harvard.edu/gazette/story/2019/02/ why-nonviolent-resistance-beats-violent-force-in-effecting-social-political-change/] (accessed [23 January 2021]). 